\title{
PERANAN METODE BERMAIN SAMBIL BELAJAR DALAM MENINGKATKAN HASIL BELAJAR MATEMATIKA PADA ANAK TUNAGRAHITA SEDANG
}

\author{
Mahbubah, \\ Muhammad Mahpur \\ Fakultas Psikologi \\ Universitas Islam Negeri (UIN) Maulana Malik Ibrahim Malang \\ Jl. Gajayana 50 Malang Telp. (0341) 558916
}

\begin{abstract}
Abstrak - Salah satu anak yang mengalami kebutuhan khusus adalah anak tunagrahita. Tunagrahita adalah kelambatan perkembangan mental seorang anak. Anak lebih lambat mempelajari berbagai hal dari anak-anak normal sebayanya. Tunagrahita memerlukan bimbingan atau layanan secara khusus untuk dapat membantunya mempelajari segala sesuatu, baik dalam hal pendidikan maupun kegiatan hidup sehari-hari (daily activity). Matematika adalah ilmu yang bersifat abstrak dan anak tunagrahita sedang mengalami kesulitan dalam memahami sesuatu yang bersifat abstrak. Oleh karena itu proses pembelajaran harus diberikan dalam bentuk kongkret, sehingga digunakan benda-benda yang bersifat nyata dan diimbangi dengan metode yang menyenangkan yaitu dengan metode bermain sambil belajar. Dengan bermain, anak tunagrahita sedang dapat belajar dan mengerjakan tugas yang diberikan dengan senang hati tanpa ada beban. Subjek penelitian ini merupakan anak tunagrahita sedang dengan keluarganya yakni ayah, ibu dan kakak di Wonojati, Pasuruan. Penelitian ini menggunakan metode penelitian tindakan dimana peneliti bekerjasama dengan keluarga anak tunagrahita sedang dalam pemberian perlakuan. Perlakuan dilakukan dengan 2 siklus dengan rincian: siklus I tentang mengenal angka dan siklus II penjumlahan. Hasil analisis menunjukan bahwa hasil belajar matematika anak tunagrahita sedang mengalami peningkatan dengan metode pembelajaran bermain sambil belajar. Subjek telah mengenal simbol angka 1-30 dan dapat menuliskan angka 1-22 tanpa melihat contoh serta dapat mengerjakan soal penjumlahan dengan total hasil maksimal 11 yakni angka 110 yang masing-masing ditambah (+) angka 1 .
\end{abstract}

Kata kunci: Bermain Sambil Belajar, Hasil Belajar, Matematika, Tunagrahita Sedang

PSIKOISLAMIKA. Jurnal Psikologi Islam (JPI) copyright @ 2014 Laboratorium Penelitian, Kajian Psikologi Islam dan Penerbitan. Volume 11. Nomor 2, Tahun 2014

\section{PENDAHULUAN}

Ada 3 kategori anak cacat mental yaitu tunagrahita ringan, tunagrahita sedang, dan tunagrahita berat. Anak tunagrahita memiliki kebutuhan khusus mengoptimalkan pencapaian potensinya. Kebutuhan khusus anak tunagrahita adalah kebutuhan dalam layanan pembelajaran. Kebanyakan guru mengajar di sekolah tempat anak tunagrahita (SLB/C) menggunakan metode ceramah yang membuat anak bosan belajar, namun kebosanan di sekolah dapat diatasi dengan peran keluarga untuk memaksimalkan potensi anak tunagrahita.

Salah satu sekolah yang menangani anak berkebutuhan khusus adalah SDLB Negeri 3 Bandaran. Di tempat inilah IN bersekolah. Suasana di sekolah ini begitu ramai dengan murid dan beberapa orang tua yang menunggui anaknya hingga pulang sekolah. Di sekolah ini terdapat 7 ruangan, ruangan pertama sebagai kantor dan ruang kepala sekolah, kemudian kelas-kelas yang mendapatkan 5 ruangan, 1 ruangan 
sisa adalah gudang. Sekolah ini memiliki murid pra hingga kelas 6. Pembagian kelasnya diacak menurut kebijakan bagian tata usaha. Ada 2 ruangan yang terpaksa diberi pembatas agar dapat mencukupi kekurangan ruang kelas. Dalam satu ruangan kelas terdapat berbagai murid dari beberapa kategori kelas dan kekhususan. Salah satunya adalah kelas yang ditempati IN. Dia menempati kelas yang satu ruangan dibagi menjadi 2 kelas. Dalam kelas IN terdapat 10 anak yang terdiri dari kelas 1, 2, 3, dan 4. Masing-masing dari mereka tidak sama kategori kekhususannya yakni terdapat 1 anak tunagrahita sedang, 1 tunagrahita ringan, 2 tunalaras, 5 anak tunadaksa, 1 tunanetra, dan 2 autis.

Cara guru mengajar di kelas itu menggunakan metode ceramah yang seharusnya tidak digunakan untuk anak-anak berkebutuhan khusus, mereka membutuhkan penanganan khusus yang berbeda dari murid normal biasanya. Guru membagi-bagi waktu untuk mengajar berbagai murid yang berbeda kelas tersebut. Biasanya guru akan memberi tugas pada kelas satu dan memintanya mengerjakan hingga selesai, kemudian memberi tugas kepada yang lainnya. Begitu juga dengan murid-murid yang lain. Terkadang guru membimbing satu murid yang dianggap paling sulit diajari dan membiarkan yang lain mengerjakan tugas mereka hingga selesai. Di kelas lain, ada guru yang memberi tugas pada seluruh murid yang ada di dalam kelasnya dan guru tersebut sibuk bermain dengan alat elektroniknya.

Menurut Plato, anak-anak akan lebih mudah mempelajari aritmatika dengan cara membagikan apel kepada anak-anak. Menurut matematika Platonisme, terdapat benda abstrak yang sepenuhnya dan terdapat kalimat matematika sejati yang memberikan gambaran yang benar dari objek. Menurut Platonis abstrak juga objek meskipun benda abstrak tidak ada dalam ruang dan tidak terbuat dari materi fisik. Teorema matematika memberikan deskripsi benar tentang objek. Urutan bilangan bulat positif adalah objek studi seperti tata surya sebagai objek studi para astronom. Dan untuk menjadikan benda-benda abstrak tersebut menjadi mudah dipahami adalah dengan menggunakan benda-benda nyata dalam belajar aritmatika. Dalam hal ini Plato menggunakan buah apel yang dibagikan kepada anak-anak agar anak lebih mudah memahami pelajaran aritmatika daripada dengan menggunakan metode membayangkan benda-benda abstrak yang kemudian ditambahkan seperti metode yang digunakan sebelumnya. Metode ini terbukti membuat anak-anak lebih mudah memahami aritmatika dengan baik karena menggunakan metode yang menyenangkan bagi anak dan memakai benda-benda yang nyata.

Jadi dalam hal ini peneliti menggunakan berbagai media yang ada di dalam rumah subjek untuk dimanfaatkan sebagai alat penunjang belajar sambil bermain seperti tablet, perabotan rumah tangga, pot bunga, tanaman-tanaman hias yang ada di halaman rumah, dan lain sebagainya.

\section{METODE}

\section{Desain Penelitian}

Jenis penelitian ini adalah penelitian tindakan dengan menggunakan model penelitian tindakan dari Kemmis dan Taggart yaitu berbentuk spiral dari satu siklus ke siklus selanjutnya. Dalam setiap siklus meliputi perencanaan, tindakan, pengamatan, refleksi dan evaluasi. Dilanjutkan pada siklus berikutnya yakni perencanaa yang sudah direvisi, tindakan, pengamatan, refleksi dan evaluasi. Dalam penelitian tindakan peneliti sebagai partisipan, fasilitator dan mediator. Peneliti juga bekerjasama dengan keluarga subjek (decision maker) dalam setiap tahap yang ada dalam penelitian tindakan agar sesuai dengan kebutuhan subjek (Suparno, 2008).

\section{Tempat, Waktu, dan Subjek Penelitian}

Tempat penelitian adalah tempat yang digunakan untuk memperoleh data yang diinginkan dalam penelitian. Tempat yang digunakan dalam penelitian ini adalah rumah IN, jalan Sambi Wonojati RT/RW 01/01 Gondangwetan, Pasuruan Jawa Timur.

Waktu penelitian adalah waktu berlangsungnya penelitian ini yaitu dilaksanakan pada semester genap periode $2013 / 2014$ pada pertengahan bulan Januari tepatnya pada tanggal 17 Januari 2014 hingga 26 Februari 2014. Penelitian ini menggunakan 3 siklus dengan masing-masing siklus memiliki 5 hari pertemuan, terdapat juga tahap percobaan selama 2 hari untuk melihat tingkat keberhasilan perlakuan. Setelah tahap percobaan, pelaksanaan siklus 1 akan membahas tentang mengenal angka, siklus 2 tentang penjumlahan, dan siklus 3 tentang membaca.

Subjek utama penelitian adalah anak tunagrahita sedang yang pada saat penelitian ini dilakukan sedang berusia 13 tahun dan sedang duduk di kelas 2 SDLB, sedangkan subjek pendukung yaitu keluarga IN (ibu, ayah dan kakak perempuan subjek).

\section{Indikator Keberhasilan}

Materi dalam pembelajaran matematika untuk anak tunagrahita sedang kelas II SLB adalah 
mengenal simbol angka 1-0 dan menulis angka 1-10, sertas membilang banyaknya benda 1-10. Dengan demikian indikator keberhasilan dalam penelitian ini adalah $\mathrm{N}$ dapat mengenal simbol angka 1-10, menulis angka 1-10, serta dapat menghitung banyaknya benda 110 .

\section{Teknik Pengumpulan Data}

Teknik pengumpulan data dalam penelitian ini adalah dengan menggunakan beberapa cara, yaitu: 1) Pengamatan partisipatif, yang dimaksud pengamatan partisipatif adalah peran peneliti dalam mengamati berbagai gejala yang terjadi dalam masalah penelitian. Fokus pengamatan diarahkan pada masalah yang menjadi pusat perhatian peneliti yakni hasil belajar matematika anak tunagrahita sedang. 2) Catatan lapangan, yaitu bukti otentik berupa catatan pokok atau catatan terurai tentang proses apa yang terjadi di lapangan sesuai dengan fokus penelitian, ditulis secara deskriptif dan reflektif. Menurut Schaltzman dan Strauss model catatan lapangan dapat diorganisasikan ke dalam tiga paket, yaitu: 1) catatan pengamatan, 2) catatan teori, 3) catatan metodologi. Catatan pengamatan berisi tentang semua peristiwa yang terjadi, apa yang dilihat, didengar dan segala apa yang teramati di lapangan, pada latar tertentu. Catatan ini berisi jawaban atas pertanyaan siapa, apa, kapan, dimana, dan bagaimana suatu peristiwa terjadi. Catatan teori merupakan bagian catatan yang berisi pendapat pengamat (peneliti) yang didasarkan pada suatu teori. Catatan teori bukan lagi berisi fakta melainkan interpretasi, pemaknaan suatu gejala (interpretive meaning). Sedangkan catatan metodologi, terkait dengan pernyataan tindakan operasional berupa kritik terhadap diri sendiri tentang cara-cara atau taktik dalam melaksanakan pengamatan di lapangan 3) Wawancara. Peneliti menggunakan wawancara tidak terstruktur (bebas) pada tata usaha sekolah dan keluarga Subjek untuk menanyakan hal apapun yang berkenaan dengan fokus penelitian terhadap Subjek. Hal tersebut dilakukan karena peneliti ingin menggali informasi sebanyak dan sedetail mungkin. 4) Dokumentasi. Dokumen yang berguna dalam pengumpulan data penelitian ini adalah "biodata Subjek" dan "nilai-nilai harian" yang dikumpulkan sebelum penelitian dimulai. Data ini dikumpulkan sebagai data sekunder untuk mendukung penelitian ini. Untuk menggambarkan kondisi awal guna membuat rencana penelitian.

\section{Instrumen Yang Digunakan}

Instrumen penelitian adalah alat yang digunakan untuk mengumpulkan data atau infomasi yang bermanfaat untuk menjawab masalah penelitian. Penelitian ini menggunakan beberapa instrumen penelitian. Yakni alat perekam, dokumentasi foto, alat perekam, dan media-media yang digunakan dalam penelitian seperti batu kerikil, kancing baju, toples, pohon, gambar, dan lain sebagainya.

\section{Keabsahan Data}

Uji keabsahan data dalam penelitian ini menggunakan monitoring data berupa portofolio dan triangulasi data. Portofolio menampilkan pekerjaan-pekerjaan subjek yang berarti sebagai hasil kegiatannya untuk memperlihatkan perkembangan subjek dalam mencapai tujuan penelitian. Portofolio dalam penelitian ini terdiri dari:

1. Daftar isi yang ditulis oleh peneliti dan orang tua

2. Artifak (sebagai bukti untuk menunjukkan pembelajaran apa yang telah dicapai siswa), dan

3. Refleksi atas pembelajaran, termasuk evaluasi pribadi dan kelompok yang dilakukan oleh peneliti dan keluarga Subjek.

Triangulasi data merupakan gabungan berbagai metode yang dipakai untuk mengkaji fenomena yang saling terkait dari sudut pandang dan perspektif yang berbeda. Dalam penelitian ini peneliti menggabungkan beberapa pendapat yang ada yakni dari peneliti sendiri, keluarga, pihak sekolah, dan ahli. Seluruh pendapat ini digabungkan untuk menghasilkan kesimpulan yang akurat terhadap assesmen dan tindakan kepada subjek dan keluarga.

Menurut Sugiyono triangulasi adalah teknik pemeriksaan keabsahan data yang memanfaatkan suatu data yang lain di luar data itu untuk keperluan pengecekan atau sebagai pembanding terhadap data itu (Denzim, 1978, dalam Moeleong, 2007). Ada beberapa macam triangulasi:

a) Triangulasi sumber, yaitu membandingkan sebuah data yang diperoleh dari sumber yang sama namun dengan alat dan waktu yang berbeda. Triangulasi sumber digunakan untuk membandingkan data yang diperoleh peneliti pada setiap harinya dengan menggunakan metode bermain sambil belajar.

b) Triangulasi metode, yaitu perbandingan dengan menggunakan berbagai metode pengumpulan data untuk menggali data yang sejenis. Pada 
triangulasi metode terdapat dua strategi, yaitu:

1) Pengecekan derajat kepercayaan penemuan hasil penelitian beberapa teknik pengumpulan data.

2) Pengecekan derajat kepercayaan beberapa sumber data dengan metode yang sama. Peneliti menggunakan berbagai metode pengumpulan data (observasi, wawancara) kemudian membandingkan hasilnya. c) Triangulasi teori, yaitu membandingkan sebuah hasil data dengan teori yang ada. Peneliti membandingkan hasil penelitian dengan teori yang telah ada.

d) Triangulasi penyidik, yaitu membandingkan hasil data dari sumber yang sama, alat yang sama namun peneliti yang berbeda. Triangulasi penyidik, yaitu dengan membandingkan hasil yang telah diperoleh menurut sudut pandang peneliti dengan decision maker.

\section{HASIL}

\begin{tabular}{|c|c|c|}
\hline Assesment Peneliti & Tulisan & Verbal \\
\hline \multirow{4}{*}{$\begin{array}{l}\text { Tunagrahita sedang } \\
\text { dengan disleksia }\end{array}$} & «G» menjadi «9» & «bah uu» untuk «abah guru» \\
\hline & $\begin{array}{l}\ll 21 » \text { menjadi «12»/ «29» menjadi } \\
\ll 92 »\end{array}$ & $\begin{array}{l}\text { «atu, ua, ga, pat, ma, mam, uh, pan, lan, uluh» untuk «satu, } \\
\text { dua, tiga, empat, lima, enam, tujuh, delapan, sembilan, } \\
\text { sepuluh" }\end{array}$ \\
\hline & «Sepeda» menjadi «sepeba» & «ma... em» untuk «mama, maem». \\
\hline & «badak» menjadi «babak» & «bah uu muk-muk» untuk «abah guru ngamuk-ngamuk» \\
\hline
\end{tabular}

\begin{tabular}{ll}
\hline «tujuh» menjadi «tujuuh» & «fekne» untuk «adekne» \\
\hline «bendungan» menjadi «benbungan» & "fung» untuk «tepung» \\
\hline «delapan» menjadi «belapan» & «hak» untuk «gak» \\
\hline «sembilan» menjadi & "eii» untuk «prei» \\
"semdilan/semdilaan» & «ma.. .pot» untuk «mama repot» \\
\hline «Luas» menjadi «idas» & « ma. .wu» untuk «lima ribu» \\
\hline «11» menjadi «77» & \\
\hline «sebelas» menjadi «sedelash» \\
\hline «baju baru» menjadi «daju daru» \\
\hline «abah» menjadi «mama»
\end{tabular}

\begin{tabular}{|c|c|c|}
\hline Assesment & $\begin{array}{l}\text { Pihak Yang Melakukan } \\
\text { Assesment }\end{array}$ & Fakta \\
\hline Autis & RS Lawang 3 tahun & $\begin{array}{l}\text { Saat subjek berusia } 3 \text { tahun Rumah Sakit Lawang memvonis subjek } \\
\text { sebagai anak autis (IY.29.6: 8c). Menurut keterangan yang didapat oleh } \\
\text { ibunya subjek memiliki pita suara yang tidak lengkap sehingga membuat } \\
\text { subjek kesulitan melafalkan kata (IY.29.6: 12a). }\end{array}$ \\
\hline Tunagrahita & Sekolah/SDLB & $\begin{array}{l}\text { Sekolah menjudge dia seperti itu langsung dari pertemuan awal tanpa } \\
\text { perlu ada psikotest terlebih dahulu karena pihak sekolah memang tidak } \\
\text { memiliki tenaga psikolog, yang ada hanya guru dari PLB. Kemudian } \\
\text { untuk mengkategorikan dia sebagai anak tunagrahita berat, sedang, } \\
\text { atau ringan adalah dengan cara memantau perkembangan subjek saat } \\
\text { berada di kelas. Dalam hal ini subjek termasuk anak tunagrahita sedang } \\
\text { (mampu latih) (TU.28.6: } 2 \text {-4). }\end{array}$ \\
\hline
\end{tabular}

Wiwiek Joewono (Praktisi Gambar yang tidak memiliki dimensi. Kemampuan yang dimiliki subjek perkembangan dan dalam gambar tersebut menunjukkan anak dengan usia 2 tahun. Dari tulisan pendidikan) tangan yang ada di buku tugas subjek Eyang Wiwiek juga menyatakan bahwa subjek merupakan anak tunagrahita mampu latih. Dalam buku tugasnya terlihat jelas bahwa subjek dapat menirukan tulisan yang diinstruksikan untuk dia contoh semampu daya tangkapnya setelahnya ada beberapa kesalahan seperti misal menambahkan huruf-huruf yang tidak ada dalam contoh atau menulis 1 huruf dalam 2 baris. Hal ini lah yang justru menurut ahli menguatkan assessment dan membedakan subjek dengan anak disleksia. Anak dengan disleksia tidak dapat menirukan contoh dengan benar melainkan huruf-hurufnya terbalik dan acak 

drawing test, scoring tersebut menghasilkan 20 - dan $9+$ dengan 29 kategori yang dilihat. Nilai + yang mencapai angka 9 menunjukkan bahwa subjek memiliki kematangan berpikir yang kurang sekali yakni berada pada angka 4. Dalam keterangannya beliau menjelaskan bahwa subjek memiliki IQ rendah. Hal ini pula yang kemudian memperjelas bahwa subjek merupakan anak tunagrahita mampu latih.

\section{PEMBAHASAN}

Perlakuan ini menerapkan prinsip-prinsip belajar untuk mengadakan perubahan. Perubahanperubahan tersebut adalah: (1) peningkatan, (2) pemeliharaan, (3) pengurangan atau penghilangan, dan (4) perkembangan atau perluasan (Purwanto, 2012).

Deskripsi hasil penelitian ini berdasarkan pada urutan kondisi subjek, yaitu kondisi pre dan post. Kondisi pre adalah kondisi sebelum subjek dan keluarga diberi perlakuan atau intervensi yang meliputi kemampuan subjek, dukungan keluarga kepada subjek dan media apa saja yang disediakan oleh keluarga untuk menunjang kegiatan subjek dalam belajar. Dalam kondisi pre ditemukan bahwa subjek sudah mengenal angka 1-3 dan dapat menuliskannya tanpa perlu ada contoh terlebih dahulu. Subjek mendapatkan dukungan berupa media tablet sebagai penunjang yang dapat membantu subjek untuk mempermudah belajarnya. Tablet tersebut diisi beberapa aplikasi yang dapat subjek gunakan untuk belajar secara menyenangkan. Selain media tablet, terdapat beberapa tempelan angka plastik dan poster angka yang dapat membantu subjek mengenal angka.

Kondisi post yaitu kondisi subjek dan keluarganya setelah perlakuan, menggambarkan orang tua bersedia bekerjasama dengan peneliti untuk mewujudkan rumah sebagai pusat belajar subjek. Hal ini merupakan dukungan awal yang baik bagi peneliti untuk dapat mengoptimalkan kemampuan subjek dan mengakrabkan subjek dengan keluarganya. Peneliti membangkitkan dan membantu menyadarkan orang tua bahwa keluarga adalah tempat belajar yang paling baik bagi subjek, rumah dapat menjadi pusat belajar yang dapat mengoptimalkan kemampuan subjek.

\section{Siklus I}

Sebelum peneliti membahas tentang perubahanperubahan yang terjadi pada siklus ini, akan dibahas terlebih dahulu tentang target-target yang telah direncanakan untuk siklus pertama ini, yaitu: a. Subjek dapat mengenal, mengucapkan dan menuliskan angka 1-20 dengan benar tanpa perlu melihat contoh.

b. Subjek dapat belajar bersama atau ditemani belajar oleh keluarga.

c. Subjek dapat menuliskan bilangan dari angka 1-5 dengan benar tanpa contoh.

Dari beberapa target yang telah dirancang sebagai tolok ukur keberhasilan pada siklus I, ada beberapa perubahan-perubahan yang terjadi pada subjek di siklus I ini. Perubahan-perubahan tersebut adalah:

a. Subjek telah mengenal simbol angka 1-20, bahkan lebih dari angka yang telah ditargetkan yakni pada angka 30. Subjek dapat menuliskan angka 1-30 dengan baik sesuai dengan batas kemampuan yang dia miliki tanpa contoh. Perubahan ini terjadi dengan dilakukannya pengulangan secara intensif dengan metode yang menyenangkan dan tidak membuat subjek bosan. Dengan metode bermain sambil belajar, subjek lebih bebas berekspresi sesuai dengan apa yang diinginkannya tanpa perlu merasa terbebani dengan pelajaran. Hal yang tak kalah penting adalah kenyamanan yang diberikan oleh keluarga. Sebelumnya, subjek tidak pernah bersedia ditemani belajar atau belajar bersama dengan keluarganya. Kenyamanan yang didapatkan subjek saat ini sangat menunjang terjadinya perkembangan yang memaksimalkan potensi yang dia miliki. Keluarga membuat subjek merasa lebih nyaman belajar di rumah, belajar yang menyenangkan.

b. Subjek belajar bersama keluarga. Pada siklus I ini sbujek telah bisa belajar bersama keluarganya tanpa merasa terganggu dengan hadirnya mereka. Dalam kondisi ini awalnya subjek mengusir anggota keluarga yang menghampiri tempat subjek belajar, namun dengan pembiasaan yang seolah-olah tidak sengaja subjek tidak menyadarinya hingga akhirnya subjek merasa nyaman sendiri dengan kondisi dimana orang tua atau kakaknya menemaninya belajar. keadaan yang dibuat di sini adalah keluarga 
sengaja di masukan ke dalam tempat dimana subjek akan belajar bersama peneliti, kemudian peneliti menghampiri keluarga tersebut dan mengajak subjek belajar di tempat yang sama. Kondisi- kondisi seperti itu selalu dilakukan berulang-ulang agar subjek lebih bisa nyaman dan terbiasa didampingi keluarganya saat belajar.

c. Subjek dapat menuliskan bilangan "satu" dengan baik tanpa perlu contoh. Perkembangan dalam bagian ini tidak sesuai dengan target yang telah direncanakan semula. Semula direncanakan bahwa subjek dapat mencapai perkembangan bilangan "satu” sampai "lima”, namun faktanya pada siklus pertama ini, subjek hanya dapat mencapai bilangan awalnya saja tanpa contoh. Tulisan bilangan yang lainnya perlu contoh terlebih dahulu baru kemudian subjek menirukan tulisan tersebut. Hal ini karena kurangnya pengulangan yang dilakukan oleh peneliti dan keluarga saat menemani subjek bermain sambil belajar.

\section{Siklus II}

Dari beberapa perubahan-perubahan yang terjadi pada siklus pertama, dilakukan evaluasi terhadap program-program yang belum tercapai. Program yang belum tercapai sesuai target adalah menulis bilangan "satu" sampai "lima". Hal ini menjadi bahan untuk diteruskan ke siklus selanjutnya. Dari perlakuan di siklus I ditemukan masalah baru yakni saat mewarnai gambar, subjek selalu menggunakan warna hitam untuk gambar yang diwarnai ataupun latarnya. Hal ini juga menjadi tambahan dalam program siklus selanjutnya. Berikut beberapa target yang dirumuskan untuk siklus II:

a. Subjek dapat menuliskan bilangan "satu" sampai bilangan "lima” tanpa melihat contoh. Hal ini merupakan program lanjutan dari siklus I yang belum tercapai sesuai target.

b. Subjek dapat mewarnai dengan warna selain hitam. Mewarnai dengan menggunakan warna hitam adalah masalah baru yang ditemukan peneliti dalam siklus I, sehingga perlu rasanya hal ini juga dimasukkan dalam target keberhasilan pada siklus II. Subjek sudah mengenal beberapa warna namun dalam mewarnai gambar yang ada di salah satu aplikasi tabletnya, dia selalu menggunakan warna hitam.

c. Belajar bersama keluarga. Pada siklus I subjek sudah bisa belajar bersama dengan keluarga, namun hubungan ini dirasa kurang dekat oleh keluarga sehingga hal ini perlu dilakukan pembiasaan lagi dalam siklus II.

d. Subjek dapat mengerjakan soal penjumlahan 1-5.

Target-target tersebut yang kemudian menjadi program dalam siklus II. Dalam siklus II, ditemukan beberapa perubahan, yaitu:

a. Bermain sambil belajar. Metode yang digunakan dalam siklus II ini sama dengan siklus I. Peneliti dan keluarga bermain bersama subjek dengan permainan edukatif yang dapat mengembangkan potensi-potensi yang dimiliki oleh subjek.

b. Subjek dapat menuliskan bilangan "satu" sampai bilangan "lima". Pengulangan lebih sering dilakukan oleh keluarga dan peneliti untuk membantu subjek mengingat bilanganbilangan tersebut.

c. Subjek dapat mewarnai dengan warna selain hitam. Pada siklus II ini subjek sudah mau menggunakan warna lain selain warna hitam untuk menghiasi gambarnya. Namun warna yang digunakan masih dominan warna gelap. Keluarga dan peneliti memasukkan konsepkonsep mewarnai dengan warna cerah secara berulang, disertai dengan contoh yang diberikan oleh kakak terlebih dahulu kemudian subjek mewarnai gambar sesuai dengan yang dicontohkan atau dengan memilih warna lain. Subjek telah bisa memilih warna berbeda dari hitam namun masih dominan pada warnawarna gelap.

d. Belajar bersama keluarga. Program ini hanya menguatkan hasil dari siklus I. subjek dibuat lebih dekat dengan keluarga. Subjek terbiasa belajar dengan keluarga tanpa perlu didampingi peneliti. Dalam kondisi ini, terkadang peneliti hanya menjadi observer dari luar tempat subjek belajar dengan keluarganya.

e. Subjek mengerjakan soal penjumlahan 1-5. Diperoleh hasil bahwa subjek telah dapat mengerjakan soal penjumlahan angka 1-10 yang masing-masing ditambah 1 . Hal ini terjadi karena orang tua sangat bersemangat dalam mengajari subjek penjumlahan dan pengulangan-pengulangan dilakukan lebih sering dari program yang lainnya. Ibu bahkan lebih sering memberikan subjek soal-soal penjumlahan yang hasil totalnya tidak lebih dari angka 11. 


\section{KESIMPULAN}

Dengan demikian kesimpulan yang diperoleh dari penelitian tindakan melalui bermain sambil belajar yang berkolaborasi dengan keluarga subjek

\section{DAFTAR PUSTAKA}

Moeleong, Lexy J. 2004. Metode Penelitian Kualitatif. Bandung: PT. Remaja Rosdakarya. dapat meningkatkan hasil belajar matematika. Penelitian yang dilaksanakan telah sesuai dengan tujuan yang diharapkan oleh peneliti dan decision maker dan sesuai dengan kebutuhan subjek.

Suparno, Paul. 2008. Riset Tindakan untuk Pendidik. Jakarta: Grasindo. 